\title{
Identification of Rhizoctonia solani Associated with Soybean in Brazil by rDNA-ITS Sequences
}

\author{
Roseli C. Fenille' ${ }^{1}$ Maísa B. Ciampi², Eiko E. Kuramae ${ }^{3}$ \& Nilton L. Souza ${ }^{2}$ \\ ${ }^{1}$ Laboratório de Apoio Vegetal, DFA-GO, MAPA, Cx. Postal 149, 74003-010, Goiânia, GO, Brazil, e-mail: \\ roselifenille@ agricultura.gov.br; ${ }^{2}$ Faculdade de Ciências Agronômicas/UNESP, Cx. Postal 237, 18603-970, Botucatu, SP, Brazil; \\ ${ }^{3}$ Centraalbureau voor Schimmelcultures - CBS, Uppsalalaan 8, 3584 CT, Utrecht, The Netherlands
}

(Accepted for publication on 03/06/2003)

Corresponding author: Roseli C. Fenille

FENILLE, R.C., CIAMPI, M.B., KURAMAE, E.E. \& SOUZA, N.L. Identification of Rhizoctonia solani associated with soybean in Brazil by rDNA-ITS sequences. Fitopatologia Brasileira 28:413-419. 2003.

\begin{abstract}
The aim of this study was to identify isolates of Rhizoctonia solani causing hypocotyl rot and foliar blight in soybean (Glycine max) in Brazil by the nucleotide sequences of ITS-5.8S regions of rDNA. The 5.8S rDNA gene sequence (155 bp) was highly conserved among all isolates but differences in length and nucleotide sequence of the ITS1 and ITS2 regions were observed between soybean isolates and AG testers. The similarity of the nucleotide sequence among AG-1 IA isolates, causing foliar blight, was $95.1-100 \%$ and $98.5-100 \%$ in the ITS1 and ITS2 regions, respectively. The nucleotide sequence similarity among subgroups IA, IB and IC ranged from 84.3 to $89 \%$ in ITS1 and

from 93.3 to $95.6 \%$ in ITS2. Nucleotide sequence similarity of $99.1 \%$ and $99.3-100 \%$ for ITS1 and ITS2, respectively, was observed between AG-4 soybean isolates causing hypocotyl rots and the AG-4 HGI tester. The similarity of the nucleotide sequence of the ITS-5.8S rDNA region confirmed that the $R$. solani Brazilian isolates causing foliar blight are AG-1 IA and isolates causing hypocotyl rot symptoms are AG-4 HGI. The ITS-5.8S rDNA sequence was not determinant for the identification of the AG-2-2 IIIB $R$. solani soybean isolate.

Additional keywords: anastomosis groups, foliar blight, hypocotyl rot, Glycine max.

\section{RESUMO}

Identificação de Rhizoctonia solani associada à soja no Brasil através de seqüências da região rDNA-ITS

O objetivo deste estudo foi identificar, através da seqüência de nucleotídeos das regiões ITS-5.8S do rDNA, isolados de Rhizoctonia solani causadores de podridão de hipocótilos e de queima foliar em soja (Glycine max), no Brasil. A seqüência do gene 5.8S do rDNA (155 bp) foi altamente conservada entre todos os isolados, mas foram observadas diferenças no tamanho e na sequiência de nucleotídeos nas regiões ITS1 e ITS2 entre os isolados obtidos de soja e os padrões de grupos de anastomose (AGs). A similaridade na seqüência de nucleotídeos entre os isolados do AG-1 IA, causadores de queima

foliar, foi 95,1-100\% na região ITS1 e 98,5-100\% na região ITS2. A similaridade na seqüência de nucleotídeos entre os subgrupos IA, IB e IC variaram de 84,3 a $89 \%$ no ITS 1 e de 93,3 a $95,6 \%$ no ITS2. Entre os isolados obtidos de soja pertencentes ao AG-4 e o padrão AG-4 HGI foram observadas $99,1 \%$ e $99,3-100 \%$ de similaridades para ITS1 e ITS2, respectivamente. Foi possível confirmar através da análise das regiões ITS-5.8S do rDNA que os isolados de $R$. solani brasileiros, causadores de queima foliar são pertencentes ao AG-1 IA e que, os isolados causadores de podridão de hipocótilos pertencem ao AG-4 HGI. A análise das regiões ITS-5.8S do rDNA não foi determinante na identificação do isolado AG-2-2 IIIB obtido de soja.
\end{abstract}

\section{INTRODUCTION}

Rhizoctonia solani Kühn [teleomorph: Thanatephorus cucumeris (Frank) Donk] is reported to cause economic losses in soybean [Glycine max (L.) Merril] crops throughout the world (Jones \& Belmar, 1989; Yang et al., 1990; Liu \& Sinclair, 1991; Muyolo et al., 1993; Naito et al., 1993; Naito et al., 1995; Embrapa, 1999). Symptoms observed on soybean plants and associated with $R$. solani infection include damping-off, roots and hypocotyl rots, web blight and aerial blight (Jones \& Belmar, 1989; Yang et al., 1990; Liu \& Sinclair, 1991; Naito et al., 1995; Embrapa, 1999). While damping-off, roots and hypocotyl rots are mainly associated with the $R$. solani anastomosis group (AG) 2-2 IIIB or AG-4, the foliar diseases are associated with AG-1 IA, AG-1 IB or AG-2-3. In Brazil, foliar blight causes losses in soybean yield ranging from 31 to $60 \%$ (Meyer \& Yorinori, 1999).

The tremendous diversity in morphology, pathogenicity and physiology of $R$. solani has led to a classification system based on anastomosis grouping. This AG is comprised of isolates among which hyphal fusion occurs; this classification system has been supported by molecular evidence. Grouping based on DNA hybridization supports previous grouping based on anastomosis (Kuninaga \& Yokosawa, 1982a and; $b_{2}=1984$, 1985; Vilgalys, 1988; Carling \& Kuninaga, 1990). Studies using restriction fragment length polymorphism (RFLP), analysis of nuclear DNA (Jabaji-Hare et al., 1990) and ribosomal DNA (rDNA) (Kuninaga et al., 1997; Gonzales et al., 2001) have also been used to identify genetic differences among some AGs. Currently, there are 13 AGs of $R$. solani, AG1 through AG13 
(Carling et al., 2002a). Among these AGs, seven have been further divided into subgroups according to culture appearance, pathogenicity, thiamin requirement, pectic zymogram patterns and molecular markers (Ogoshi, 1987; MacNish et al., 1993; Kuninaga et al., 1997; Gonzales et al., 2001).

Sequence analysis of the $18 \mathrm{~S}, 28 \mathrm{~S}$ and $5.8 \mathrm{~S}$ transcriptional units and the internal transcribed spacers (ITS) of the rDNA genes has been used to infer taxonomic and phylogenetic relationships among the different AGs of $R$. solani and Rhizoctonia spp (Gonzalez et al., 2001; Carling et al., 2002a, b). The AG-1 and AG-4, which are particularly associated with soybean in Brazil (Fenille et al., 2002), were split into different subgroups based on a phylogenetic analysis of the ITS1, ITS2 and 5.8S rDNA regions by asymmetric PCR sequencing techniques, correlated with ecological habitat and virulence (Kuninaga et al., 1997).

This study describes the rDNA ITS1-5.8S-ITS2 sequence analysis used to identify subgroups in $R$. solani causing aerial blight and hypocotyl rot on soybeans in Brazil. We compared the rDNA sequence data from Brazilian isolates with the available data for other isolates obtained throughout the world.

\section{MATERIALSANDMETHODS}

\section{Pathogenicity tests}

The isolates obtained from soybean seedlings showing hypocotyl rot symptoms were tested on soybean cv. 'FTCristalina' under greenhouse conditions at $25 \pm 2{ }^{\circ} \mathrm{C}$, in soil at $\mathrm{pH}$ 4.5. Inoculum was prepared as described previously (Fenille $\&$ Souza, 1999). A completely randomized design with five replicate pots per isolate was used. After 15 days, disease severity was assessed using the scale described by Davey \& Papavizas (1959) and Fenille \& Souza (1999). The isolates derived from plants with foliar blight were evaluated by an $i n$ vitro detached-leaf assay carried out using healthy leaves of 55-day-old soybean plants cv. 'Xingu' at $26 \pm 1^{\circ} \mathrm{C}$ (Muyolo et al., 1993).

\section{ITS-5.8S gene sequencing}

DNA extraction - Rhizoctonia solani isolates used for DNA extraction (Table 1 and 2) were grown in $100 \mathrm{ml}$ potato dextrose broth in $250-\mathrm{ml}$ flasks inoculated with mycelial $0.5 \mathrm{~cm}$ plugs. Cultures were incubated on an orbital shaker $(150 \mathrm{rpm})$ at $26^{\circ} \mathrm{C}$ for five days in the dark. Fungal mycelium was harvested by filtering through Whatman filter paper. The mycelium was then ground in liquid nitrogen and total genomic DNA was extracted by the method of Kuramae-Izioka (1997).

Polymerase chain reaction for nucleotide sequencing - Initial amplifications were performed using the ITS4/ITS5 primer set for amplifying the ITS and 5.8S subunit of the nuclear ribosomal RNA gene (White et al., 1990). Amplifications (50 $\mu \mathrm{l})$ were performed using $100 \mathrm{ng}$ of genomic DNA, $1.5 \mathrm{mM} \mathrm{MgCl}_{2}, 2 \mathrm{U}$ Taq polymerase (Gibco Life Technologies), $0.2 \mathrm{mM}$ of each $\mathrm{dNTP}, 50 \mathrm{mM} \mathrm{KCl}, 10 \mathrm{mM}$ Tris- $\mathrm{HCl}$, and $0.2 \mu \mathrm{M}$ of each primer.
A 5- $\mu \mathrm{l}$ aliquot of milliQ water was used instead of target DNA as a negative control. A MJ Research PTC-100 thermocycler was used with the following program: an initial denaturation at $94{ }^{\circ} \mathrm{C}$ for $2 \mathrm{~min}$; followed by 35 cycles of $94^{\circ} \mathrm{C} / 1 \mathrm{~min}, 55^{\circ} \mathrm{C} / 1$ $\min$ and $72^{\circ} \mathrm{C} / 2 \mathrm{~min}$, and a final extension at $72^{\circ} \mathrm{C}$ for $5 \mathrm{~min}$. The PCR product of each isolate was electrophoresed on $1.0 \%$ (w/ v) agarose gel in TBE buffer (Sambrook et al., 1987), stained with ethidium bromide and visualized under UV lights.

DNA sequencing and data analysis - Each PCR product was purified using MicroSpin S-400 HR columns (Amersham Pharmacia) according to the manufacturer's instructions. Isolates were sequenced using a double-stranded DNA template of each PCR product ( $75 \mathrm{ng}$ ) and $1 \mu \mathrm{M}$ each of the ITS2, ITS3, ITS4 or ITS5 primers following the protocol supplied with the Amersham Premix Terminator (Amersham Pharmacia). Sequencing was performed using a PE Applied Biosystems Model 377 DNA Sequencer as recommended by the manufacturer. The four sequence fragments obtained with the four primers of each isolate were assembled using Phred/Phrap/

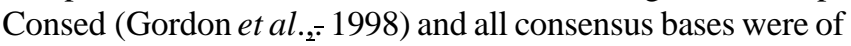
high quality with a Phred value of at least 20 . The ITS sequences and 5.8S rDNA data of all isolates were aligned using the computer software package CLUSTAL X (Thompson et al., 1997). The alignment of all sequences was checked visually. The tree showing the similarity among isolates was constructed from distance matrix values by the neighbor-joining method and 1,000 bootstrap values were calculated using the CLUSTAL X software. Phylogenetic relationships also were determined by the maximum parsimony method from Phylogenetic Analysis Using Parsimony (PAUP) (Swofford, 2001). Branch support was assessed by bootstrap analysis based on 100 replicate heuristic searches using the "fast bootstrap" option in PAUP. Rhizoctonia sp. AG-Ba was included as outgroup.

\section{RESULTS}

\section{Pathogenicity tests}

The five soybean isolates associated with hypocotyl rot symptoms caused root and hypocotyl rot on soybean seedlings in the greenhouse with disease indexes ranging from 3.4 to 6.0 (0-7 scale) (Table 1). All isolates associated with soybean foliar blight caused foliar lesions on soybean plants in detached-leaf assay with disease indexes from 0.7 to 2.4 (04 scale) (Table 1).

\section{ITS-5.8S gene sequencing}

Genomic DNA of five $R$. solani isolates causing hypocotyl rot, eight isolates causing aerial blight of soybean, and nine AG testers (AG-1 IA, AG-1 IB, AG-4 HGI, AG-4 HGII, AG-4 HGIII, AG-2-1, AG-2-2 IIIB, AG-2-2 IV, and AG-2-3) were used as template for the amplification of the ITS1 and ITS2 regions and of the 5.8S rDNA gene. Sequences of the same regions of the AG tester AG-1 IC (AB000035) were obtained from the National Center for Biotechnology Information (NCBI). 
Identification of Rhizoctonia solani associated with soybean in Brazil...

TABLE 1 - Anastomosis group, symptoms, geographic origin, and disease severity indexes of Rhizoctonia solani isolates used in this study

\begin{tabular}{lllcl}
\hline \hline Isolate & AG/subgroup $^{\mathbf{a}}$ & \multicolumn{1}{c}{ Symptoms/Host/Origin $^{\text {Severity }}$} & Accession n $^{\mathbf{b}}$ \\
\hline SJ 16 & AG-1 IA & Foliar blight, Lucas do Rio Verde -MT (field 1) & 2.1 & AY270010 \\
SJ 19 & AG-1 IA & Foliar blight, Lucas do Rio Verde -MT (field 1) & 2.2 & AY270013 \\
SJ 24 & AG-1 IA & Foliar blight, Lucas do Rio Verde -MT (field 2) & 1.9 & AY270008 \\
SJ 26 & AG-1 IA & Foliar blight, Lucas do Rio Verde -MT (field 2) & 0.7 & AY270009 \\
SJ 28 & AG-1 IA & Foliar blight, Lucas do Rio Verde -MT (field 2) & 1.2 & AY270006 \\
SJ 34 & AG-1 IA & Foliar blight, Lucas do Rio Verde -MT (field 3) & 2.4 & AY270007 \\
SJ 57 & AG-1 IA & Foliar blight, Lucas do Rio Verde -MT (field 3) & 1.8 & AY270012 \\
SJ 67 & AG-1 IA & Foliar blight, Lucas do Rio Verde -MT (field 3) & 0.9 & AY270011 \\
SJ 07 & AG-2-2 IIIB & Hypocotyl rot, Taquarituba-SP & 3.4 & AY270015 \\
SJ 01 & AG-4 HGI & Hypocotyl rot, Sao Gotardo-MG & 3.5 & AY270001 \\
SJ 02 & AG-4 HGI & Hypocotyl rot, Ponta GrossaPR & 4.1 & AY270003 \\
SJ 03 & AG-4 HGI & Hypocotyl rot, Londrina-PR & 5.7 & AY270004 \\
SJ 05 & AG-4 HGI & Hypocotyl rot, Taquarituba-SP & 6.0 & AY270002 \\
\hline
\end{tabular}

${ }^{a}$ AG-1 IA was determined by hyphal anastomosis, mycelial growth rate, sclerotium type, RAPD analysis and rDNA-ITS sequences. AG-2-2 IIIB was determined by hyphal anastomosis, thiamine requirement, temperature range to grown and RAPD analysis. AG-4 HGI was determined by hyphal anastomosis, RAPD analysis and rDNA-ITS sequences.

${ }^{\mathrm{b}}$ Isolates SJ 16, 19, 24, 26, 28, 34, 57, and 67: 0-4 scale (0, no infection; 1, 1-25\% of leaf area blighted; 2, 26-50\%; 3, 51-75\%; and 4, 76-100\% of leaf area blighted). Disease indexes were assessed on soybean cv. "Xingu" by an in vitro detached-leaf assay.

c Isolates SJ 01, 02, 03, 05, and 07: 0-7 scale (0, plants with no visible infection; 1, typical discoloration of the lower stem, cotyledons, and roots but no lesions; 2, small lesions; 3, large lesions; 4, lesions extensive enough to surround at least 50\% of the stem; 5, plants completely girdled; 6, post-emergence damping-off; 7, pre-emergence damping-off). Disease indexes were assessed on soybean cv. "FT-Cristalina" 15 days after inoculation.

The distance among all Brazilian soybean isolates and the AG testers are shown in Figure 1. The 5.8S rDNA gene sequence (155 bp) was highly conserved among isolates. Only isolate SJ34 and the AG-2-2 IV tester had single-base substitution in the 5.8S rDNA gene.

The ITS1 and ITS2 regions varied in length between soybean isolates and AG testers. A variable length of 205-213 bp and 282-283 bp was observed for ITS1 and ITS2, respectively, among AG-1 IA isolates. The nucleotide sequence similarity among AG-1 IA isolates was $95.1-100 \%$ in the ITS1 region and $98.5-100 \%$ in the ITS2 region. The similarity in nucleotide sequence among subgroups IA, IB and IC ranged from 84.3 to $89.0 \%$ in ITS1 and from 93.3 to $95.6 \%$ in ITS2. The clustering of the isolates of subgroup AG-1 was supported by a $97 \%$ bootstrap value (Figure 1).

There was no variation in ITS 1 or ITS2 length among AG-4 soybean isolates. The fragments were 216 and $281 \mathrm{bp}$ for ITS1 and ITS2, respectively. Nucleotide sequence similarity of 99.1\% and $99.3-100 \%$ for the ITS1 and ITS2 regions, respectively, was observed between AG-4 soybean isolates and the AG-4 HGI tester. Nucleotide sequence similarity between the same AG-4 soybean isolates and the AG-4 HGII tester was $94.4-95.3 \%$ and $96.8-97.1 \%$ for ITS1 and ITS2, respectively. The AG-4 HGIII tester showed length polymorphism (297bp) in the ITS2 region when compared to AG-4 HGI tester and AG-4 HGI soybean isolates (281 bp) and

TABLE 2 - Tester isolates of Rhizoctonia solani used in this study

\begin{tabular}{llllc}
\hline \hline AG/subgroup & \multicolumn{1}{c}{ Isolate } & \multicolumn{1}{c}{ Host } & \multicolumn{1}{c}{ Collector or supplier } & Accession n $^{0^{0}}$ \\
\hline AG 2-1 & PS-4 & Pea & A. Ogoshi - Tokushima, Japan & AY154317 \\
AG 2-3 & - & Soybean & S. Naito - Tohoku, Japan & AY154312 \\
AG2-2 IV* & BC-10 & Sugar beet & S. Kuninaga - Hokkaido, Japan & AB000014 \\
AG2-2 IV & RI-64 & Sugar beet & A. Ogoshi - Ibaraki, Japan & AY270014 \\
AG2-2 IIIB* & B-60 & Sugar beet & S. Kuninaga - Okayama, Japan & AB000013 \\
AG2-2 IIIB & - & Soybean & J. B. Sinclair - Illinois, United States & AY154311 \\
AG-1 IA & H5-526 & Maize & S. Naito - Tohoku, Japan & AY154301 \\
AG-1 IB & - & Lettuce & L. J. Herr - Ohio, United States & AY154302 \\
AG-1 IC & RH-28 & Sugar beet & S. Kuninaga - Hokkaido, Japan & AB000035 \\
AG-4 HGI & AH-1 & Peanut & A. Ogoshi - Chiba, Japan & AY154307 \\
AG-4 HGII & - & - & S. Kuninaga - Japan & AY270005 \\
AG-4 HGIII & 45Rs & Sugar beet & J. Kotila - United States & AY154309 \\
AG-4 HGII & RSA & Snapbean & M. Boysen - Spain & U19964 \\
AG-4 HGI & Rh 13 & Soil & M. Boysen - Spain & U19960 \\
\hline
\end{tabular}




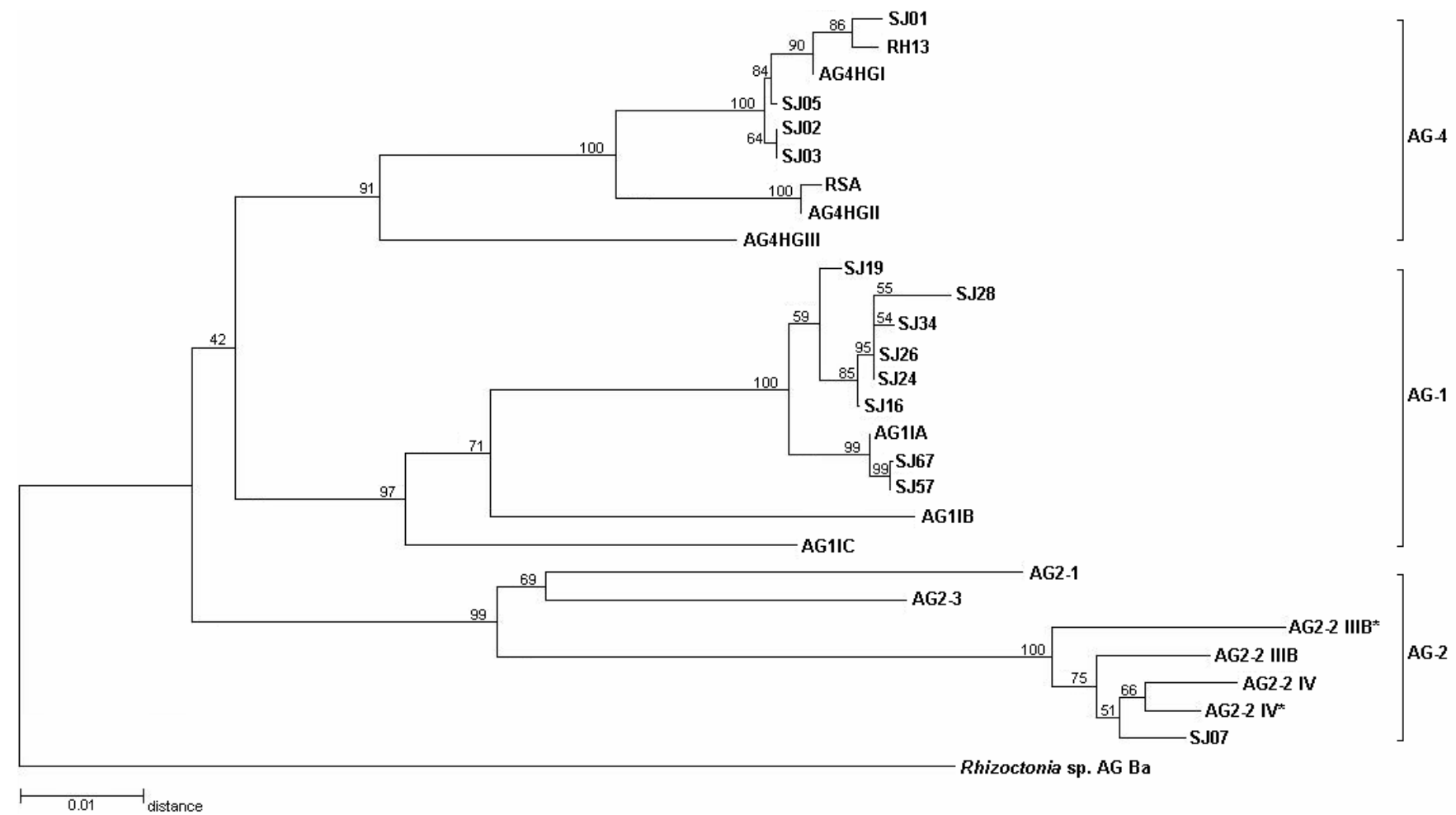

FIG. 1 - Neighbor-joining tree illustrating the distance relationships derived from sequences of the ITS-5.8S rDNA regions of AG-1, AG-2 and AG-4 isolates of Rhizoctonia solani, causing of foliar blight and hypocotyl rot, respectively of soybean (Glycine max) (Table 1). The numbers at the branch points indicate the percentages of bootstrap values

the AG-4 HGII tester (279bp). Similarity between the AG-4 isolates and the AG-4 HGIII tester was $81.2-83.3 \%$ in the ITS1 region and $93.9-94.5 \%$ in the ITS2 region. All AG-4 isolates clustered with $91 \%$ bootstrap support and the clustering of the AG-4 soybean isolates and the AG-4 HGI tester had a 100\% bootstrap value (Figure 1).

The soybean isolate previously characterized as AG-22 IIIB had 235 and 284 bp in the ITS1 and ITS2 regions, respectively. The nucleotide sequence similarity between the soybean isolate and the AG-2-2 IIIB tester was $97.9 \%$ for both ITS regions. When the same isolate was compared to the AG2-2 IV tester, the similarity was 97.4 and $99.3 \%$ for ITS1 and ITS2, respectively. The similarity between the soybean isolate and AG 2-1 was $77.2 \%$ (ITS1) and $96.3 \%$ (ITS2) and the similarity between the same isolate and the AG 2-3 tester was $82.9 \%$ (ITS1) and 92.5\% (ITS2).

In the phylogenetic analysis 729 aligned positions were included and 155 positions were phylogenetically informative. Parsimony analysis yielded tree with a length of $458(\mathrm{CI}=$ $0,721, \mathrm{RI}=0,871, \mathrm{RC}=0,628$ ) (Figure 2). Phylogenetic analysis of the ITS sequence data revealed well supported terminal groupings that correspond with previously recognized $\mathrm{AG}$ or AG subgroups that were also obtained in the neighbor joining analysis.

\section{DISCUSSION}

Similar results were obtained in the present study using the same $R$. solani isolates from soybean as used in a previous work (Fenille et al., 2002). The present study corroborated the characterization of the isolates causing foliar blight in the IA subgroup, because the Brazilian AG-1 IA isolates had more than $95.1 \%$ similarity in the ITS1 region and more than $98.5 \%$ similarity in the ITS2 region with the AG-1 IA testers from Japan. Although the AG-1 IA isolates were collected from three distinct Brazilian soybean fields (Table 1), it was not possible to cluster them according to geographical origin by ITS-rDNA sequences. Fragment length polymorphism of the ITS1 and ITS2 regions was observed among AG-1 IA isolates from field 1 and field 3. Kuninaga et al. (1997) also detected differences in ITS regions length fragments of AG-1 IA isolates. The similarity range in the ITS1 region of the soybean AG-1 IA isolates was broader than the similarity of the AG-1 IA subgroups, as also observed by Kuninaga et al. (1997). The difference was probably due the greater number of isolates analyzed in the present study. More variable nucleotide sequences of the ITS regions of the three AG-1 subgroups was obtained in the present study than by Kuninaga et al. (1997). However, we observed lower similarity among the three AG-1 subgroups in the ITS1 region than in the ITS2 region, also observed by Kuninaga et al. (1997). As suggested by Kuninaga et al. (1997), the ITS1 region may be more useful for the characterization of the AG-1 subgroups.

The AG-4 isolates from soybean (Table 1) showed high similarity in the ITS region sequences with the AG-4 HGI tester. 


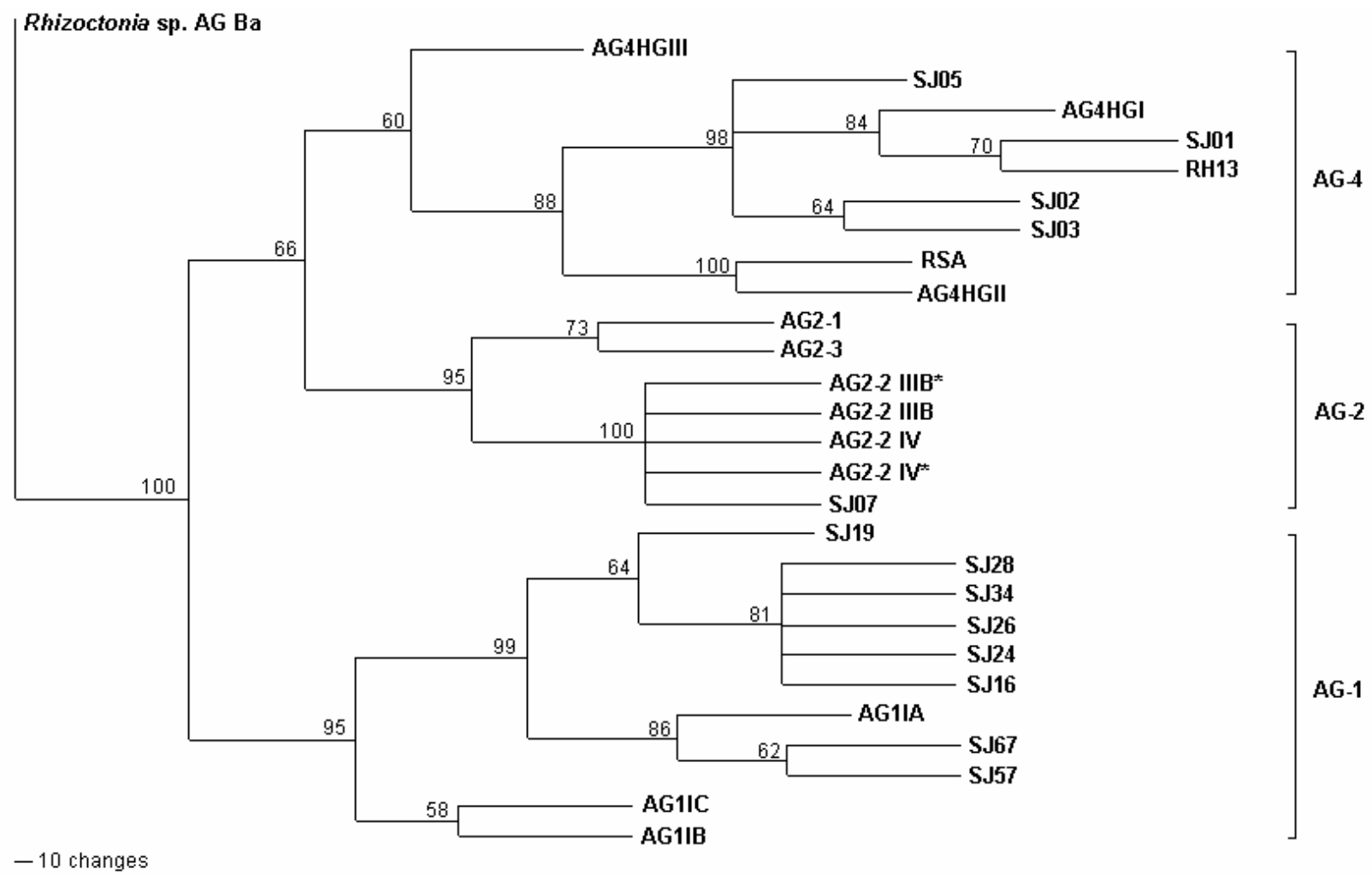

FIG. 2 - A single most parsimonious tree based on phylogenetic analyses with PAUP* (Swofford, 2001) of internal transcribed spacer (ITS) regions of rDNA of AG-1, AG-2 and AG-4 isolates of Rhizoctonia solani, causing of foliar blight and hypocotyl rot, respectively of soybean (Glycine max) (Table 1). Consistency index $(\mathrm{CI})=0,721$, and retention index $(\mathrm{RI})=0,871$. The relative support for each clade is indicated by bootstrap values on branches

Interestingly, sequence similarity was greater than that observed by Kuninaga et al. (1997) among six Japanese AG-4 HGI isolates. Also the similarity between the soybean isolates and the AG-4 HGII tester was higher than the similarity between the HGI and HGII subgroups reported by Kuninaga et al. (1997). In the present study it was also possible to evidence the subgroup HGIII on same branch with AG-4 isolates. The nucleotide sequences of isolates Rh13 and RSA (Boysen et al., 1996) were also compared to subgroups HGI and HGII and were found to be more closely related to subgroups HGI and HGII, respectively, than to subgroup HGIII, as also observed by Kuninaga et al. (1997) (Figure 1). According to previous studies (Fenille, 2001), the AG-4 HGIII tester anastomosed to three soybean isolates characterized as AG-4 HGI but at lower frequency than to the AG-4 HGI tester. The present study clearly confirmed that the Brazilian isolates causing hypocotyl rot on soybean belonged to the HGI subgroup.

We could not assign the soybean isolate $\mathrm{SJ} 07$ to subgroup AG 2-2 IIIB or AG 2-2 IV by analyzing only the rDNA sequences. In contrast, Lübeck \& Poulsen (2001) could separate AG 2-2 IIIB and AG 2-2 IV by UP-PCR using universal primers and by rDNA-RFLP. The identification of the same soybean isolate as AG-2-2 IIIB by hyphal anastomosis, pathogenicity, thiamin requirement, growth temperature and RAPD analysis (Fenille et al., 2002) was not supported by the ITS-rDNA nucleotide sequence analysis. There was a high degree of similarity in the ITS1 region of the soybean isolate and the AG2-2 IIIB tester, but in the ITS2 region this soybean isolate was more similar to the AG-2-2 IV tester. The nucleotide sequences of the soybean isolate were also compared to the sequences of AG-2-2 IIIB and AG-2-2 IV obtained by Kuninaga et al. (1997) and the subgroups IIIB and IV clustered together with other subgroup AG-2 testers (Figure 1), as also observed by Kuninaga et al. (1997). The difference between the Brazilian isolate and the AG-2-2 testers was only $0.5 \%$ in the ITS 1 region while the variation was at least $4.6 \%$ within the AG-1 and AG4 subgroups. According to Kuninaga et al. (2000), the sequence variation of ITS 1 ranged from 0 to $4 \%$ in the same subgroup/ AG, from 9 to $34 \%$ in different subgroups within the same AG, and from 11 to $45 \%$ in different AGs. Although we analyzed only one AG-2-2 isolate, the comparison of the ITS nucleotide sequences would not be enough to separate different subgroups of AG-2-2. Carling et al. (2002a) also reported that the three subsets of AG-2-2, (IIIB, IV, and LP) formed a unique cluster when a phylogenetic relationship among seven subsets of AG-2 was carried out.

Different symptoms were observed on plants inoculated with the two different AGs obtained from soybean seedlings with hypocotyl rot. The AG-2-2 IIIB isolate essentially infected the roots, while AG-4 HGI isolates caused 
lesions on the hypocotyls. In the seedlings inoculated with the AG-2-2 IIIB isolate, the lesions were larger than those caused by AG-4 HGI isolates; also cortex tissue exhibition of the hypocotyl and root were seen in plants inoculated with the AG-2-2 IIIB isolate. Lesions caused by AG-4 HGI isolates were delimited, sunken, and had a dark border, but without cortex tissue exhibition. Muyolo et al. (1993) also reported that AG-4 isolates were more virulent on hypocotyls than on soybean roots, whereas AG-2-2 IIIB isolates were more virulent on roots than on hypocotyls.

The ITS sequences published here should facilitate the development of further AG-1 IA and AG-4 HGI specific PCR primers for use in plant health monitoring and facilitate a rapid and reliable identification of a large number of isolates. A similar application was described for AG-3. Specific primer sets for the detection of the two subgroups, potato and tobacco type, were developed from the aligned rDNA-ITS sequences (Kuninaga et al., 2000). Carling et al. (2002a) also designed group-specific primer pairs for each of the seven subsets of AG-2 based on the rDNA-ITS sequences. According to Carling et al. (2002b) subsets of AGs can be distinguished from the other subsets only by use of criteria such as host range, virulence, or certain molecular tests.

The confirmation of the occurrence of AG-1 IA infecting soybeans in Brazil and causing foliar blight suggesting that the primary source of inoculum for these infections was either sclerotia or hyphae in soil organic debris. This information is relevant for the application of chemical control that could be made directly to the soil or to the plants (Pascual et al., 2000). According to Jones \& Belmar (1989), there are differences between IA and IB subgroups related to optimal growth temperature, fungicide sensitivity, and favorable propagule survival conditions. The cited authors concluded that this information is very important and also necessary for the appropriate selection of isolates for resistance-screening programs. Differentiation between the subgroups of AG-1 is important in intercropping or crop rotation decisions because AG-1 IA can be pathogenic to several crops such as corn and bean (Pascual et al., 2000), which have been frequently utilized in rotation with soybean in the "Cerrados".

\section{ACKNOWLEDGEMENTS}

The authors wish to thank Dr. J.B. Sinclair (University of Illinois, Urbana-Champaign, USA). Dr. A. Ogoshi (Hokkaido University, Sapporo, Japan). Dr. L. J. Herr (Ohio State University, Wooster, USA). Dr. S. Naito (Tohoku National Agricultural Experiment Station, Morioka, Japan) and Dr. M.A. Cubeta (Duke University, North Carolina, USA) for supplying the tester strains of $R$. solani. We are also indebted to Dr. P.C. Cereseni (Universidade Estadual Paulista, Ilha Solteira, São Paulo, Brazil) and Dr. J.T. Yorinori (CNPSo-Embrapa, Londrina, Parana, Brazil) who provided additional Rhizoctonia isolates. A fellowship from Fundação de Amparo à Pesquisa do Estado de São Paulo - FAPESP is gratefully acknowledged by the first author.

\section{LITERATURE CITED}

BOYSEN, M., BORJA, M., DELMORAL, C., SALAZAR, O. \& RUBIO, V. Identification at strain level of Rhizoctonia solani AG4 isolates by direct sequences of asymmetric PCR products of the ITS regions. Current Genetics 29:174-181. 1996.

CARLING, D.E. \& KUNINAGA, S. DNA based-sequence homology in Rhizoctonia solani Kuhn: inter- and intra-group relatedness of anastomosis group-9. Phytopathology 80:1362-1364. 1990.

CARLING, D.E., KUNINAGA, S. \& BRAINARD, K.A. Hyphal anastomosis reactions, rDNA-internal transcribed spacer sequences, and virulence levels among subsets of Rhizoctonia solani anastomosis group-2 (AG-2) and AG-BI. Phytopathology 92:43-50. 2002a.

CARLING, D.E., BAIRD, R.E., GITAITIS, R.D., BRAINARD, K.A., KUNINAGA, S. Characterization of AG-13, a newly reported anastomosis group of Rhizoctonia solani. Phytopathology 92:893899. 2002b.DAVEY, C.B. \& PAPAVIZAS, G.C. Effect of organic soil amendments on the Rhizoctonia disease of snap beans. Agronomy Journal 51:493-496. 1959.

EMBRAPA Recomendações técnicas para a cultura da soja na região central do Brasil 1999/2000. Londrina. Embrapa Soja. Documentos, 132. 1999.

FENILLE, R.C. Caracterização citomorfológica, cultural, molecular e patogênica de Rhizoctonia solani Kühn associado à soja no Brasil. (Tese de Doutorado). Universidade Estadual Paulista. 2001.

FENILLE, R.C. \& SOUZA, N.L. Efeitos de materiais orgânicos e da umidade do solo na patogenicidade de Rhizoctonia solani Kühn AG4 HGI ao feijoeiro. Pesquisa Agropecuária Brasileira 34:1959-1967. 1999.

FENILLE, R.C., SOUZA, N.L. \& KURAMAE, E.E. Characterization of Rhizoctonia solani associated with soybean in Brazil. European Journal of Plant Pathology 108:783-792. 2002.

GONZALES, D., CARLING, D.E., KUNINAGA, S., VILGALYS, R. \& CUBETA, M.A. Ribosomal DNA systematics of Ceratobasidium and Thanatephorus with Rhizoctonia anamorphs. Mycologia 93:1138-1150. 2001.

GORDON, D., ABAJIAN, C. \& GREEN, P. Consed: a graphical tool for sequence finishing. Genome Research 8:195-202. 1998.

JABAJI-HARE, S.H., MELLER, Y., GILL, S. \& CHAREST, P.M. Investigation of genetic relatedness among anastomosis groups of Rhizoctonia solani using cloned DNA probes. Canadian Journal of Plant Pathology 12:393-404. 1990.

JONES, R.K. \& BELMAR, S.B. Characterization and pathogenicity of Rhizoctonia spp. isolated from rice, soybean, and other crops grown in rotation with rice in Texas. Plant Disease 73:1004-1010. 1989.

KUNINAGA, S. \& YOKOSAWA, R. DNA based sequence homology in Rhizoctonia solani Kuhn. I. Genetic relatedness within anastomosis group 1. Annals of the Phytopathological Society of Japan 48:659667. 1982a.

KUNINAGA, S. \& YOKOSAWA, R. DNA based sequence homology in Rhizoctonia solani Kuhn. II. Genetic relatedness within anastomosis group 2. Annals of the Phytopathological Society of Japan 48:668673. 1982 b.

KUNINAGA, S. \& YOKOZAWA, R. DNA sequence homology in Rhizoctonia solani Kuhn. VI. Genetic relatedness within AG-4. Annals of the Phytopathological Society of Japan 50:346-352. 1984. 
Identification of Rhizoctonia solani associated with soybean in Brazil...

KUNINAGA, S. \& YOKOSAWA, R. DNA based sequence homology in Rhizoctonia solani Kuhn. VI. Genetic relatedness within anastomosis group 2. Annals of the Phytopathological Society of Japan 51:127-132. 1985.

KUNINAGA, S., NATSUAKI, T., TAKEUCHI, T. \& YOKOSAWA, $R$. Sequence variation of the rDNA ITS regions within and between anastomosis groups in Rhizoctonia solani. Current Genetics 32:237243. 1997.

KUNINAGA, S., CARLING, D.E., TAKEUCHI, T. \& YOKOSAWA, R. Comparison of rDNA-ITS sequences between potato and tobacco strains in Rhizoctonia solani AG-3. Journal of General Plant Pathology 66:2-11. 2000.

KURAMAE-IZIOKA, E.E. A rapid. easy and high yield protocol for total genomic DNA isolation from Colletotrichum gloeosporioides and Fusarium oxysporum for RAPD. Revista Unimar 19:683-689. 1997.

LIU, Z. \& SINCLAIR, J.B. Isolates of Rhizoctonia solani anastomosis group 2-2 pathogenic to soybean. Plant Disease 75:682-687. 1991.

LÜBECK, M. \& POULSEN, H. UP-PCR cross blot hybridization as a tool for identification of anastomosis groups in the Rhizoctonia solani complex. FEMS Microbiology Letters 201:83-89. 2001.

MAcNISH, G.C., CARLING, D.E. \& BRAINARD, K.A. Characterization of Rhizoctonia solani AG-8 from bare patches by pectic isozyme (zymogram) and anastomosis techniques. Phytopathology 83:922-927. 1993.

MEYER, M.C. \& YORINORI, J.T. Incidência de doenças da soja em regiões tropicais. Congresso Brasileiro de Soja. Londrina. 1999. pp.457. (Abstract).

MUYOLO, N.G., LIPPS, P.E. \& SCHMITTHENNER, A.F. Anastomosis grouping and variation in virulence among isolates of Rhizoctonia solani associated with dry bean and soybean in Ohio and Zaire. Phytopathology 83:438-444. 1993.

NAITO, S., MOCHIDA, H., NAKAJIMA, T. \& OHTO, Y. Infection with basidiospores of Thanatephorus cucumeris (AG-2-
3 of Rhizoctonia solani) and development of soybean foliar blight lesions. Annals of the Phytopathological Society of Japan 61:362368. 1995.

NAITO, S., MOHAMAD, D., NASUTION, A. \& PURWANTI, H. Soil-borne diseases and ecology of pathogens on soybean roots in Indonesia. JARQ - Japan Agricultural Research Quarterly 26:247253. 1993.

OGOSHI, A. Ecology and pathogenicity of anastomosis and intraspecific groups of Rhizoctonia solani Kühn. Annual Review of Phytopathology 25:125-143. 1987.

PASCUAL, C.B., TODA, T., RAYMONDO, A.D. \& HYAKUMACHI, M. Characterization by conventional techniques and PCR of Rhizoctonia solani isolates causing banded leaf sheath blight in maize. Plant Pathology 49:108-118. 2000.

SAMBROOK, J., FRITSCH, E.F. \& MANIATIS, T. Molecular cloning: A Laboratory Manual. New York. Cold Spring Harbor Laboratory Press. 1987.

SWOFFORD, D.L. PAUP*. Phylogenetic Analysis Using Parsimony (*and other methods), Version 4.0b5a. Sunderland, Massachusets: Sinauer Associates. 2001.

THOMPSON, J.D., GIBSON, T.J., PLEWNIAK, F., JEANMOUGIN, F. \& HIGGINS, D.G. The ClustalX windows interface: flexible strategies for multiple sequence alignment aided by quality analysis tools. Nucleic Acids Research 25:4876-4882. 1997. VILGALYS, R. Genetic relatedness among anastomosis groups in Rhizoctonia solani as measured by DNA/DNA hybridization. Phytopathology 78:698-702. 1988.

WHITE, T.J., BRUNS, T., LEE, S. \& TAYLOR, J.W. Amplification and direct sequencing of fungal ribosomal RNA genes for phylogenetics. In: Innis, M.A., Gelfand, D.H., Sninsky, J.J. \& White, T.J. (Eds.) PCR Protocols: A Guide to Methods and Applications. San Diego. Academic Press. 1990. pp.315-322.

YANG, X.B., BERGGREN, G.T. \& SNOW, J.P. Types of Rhizoctonia foliar blight on soybean in Louisiana. Plant Disease 74:501-504. 1990. 